comes from the observation that hotspot traces cross over ridge axes such as the Ninety east Ridge and Kerguelen Island in the Indian ocean and several hotspots in the Atlantic ${ }^{8}$. If the hotspots were generated by facture propagation with their magma sources heterogeneously distributed at shallow levels in the convecting mantle, then the cross-over process should have erased all memory of thermal perturbation related to hotspots and, indeed, the hotspots themselves. Consequently, their source must be deeper than the immediate source region for MORB.

One possible snag with the proposals of Schilling et al. is that they require that divergent convective motion is inoperative under the ridge axis. It is not clear that this is the case. The possibility that advective overflow of the hot buoyant plume material along the connecting channel to the ridge axis could have been decoupled from the underlying convective upper mantle deserves further evaluation.

A by-product of plume material intrusion and entrainment in the depleted upper mantle is the creation of local heterogeneities - as envisaged in the plum-pudding type models. Consequently, plume and plum-pudding models need not be mutually exclusive in a dynamic mantle, which could very well satisfy geochemical and isotopic data observed in many isolated seamounts with no obvious connection to long-lived hotspot traces. That the $\mathrm{Pb}$ and $\mathrm{Sr}$ isotope compositions of basalts from Gough, Tristan da Cunha, Kerfuelen Island and St Helena are unusual compared with most hotspots, offers the change of further quantitative evaluation of the plume-ridge interaction and the plum-pudding formation process.

Finally, what about the source and cause of mantle plumes? Several models have been proposed, most of which are related to the fate of the subducted oceanic lithosphere ${ }^{9}$. If this is not smeared out by viscous flows and distributed back into the convecting upper mantle to generate ubiquitous heterogeneity, it could congregate into a distinct density layer, perhaps at the base of the upper mantle (about $650 \mathrm{~km}$ deep). Thermal disturbances in the deep mantle could then trigger density instabilities in this layer, inducing partial melting and plume upwelling. Such a subduction-revival cycle could take hundreds of millions of years. A spectrum ranging from pure 'chemical' to 'thermal' plumes could thus be generated according to the degree of mixing between the material derived from the subducted lithosphere and the depleted upper mantle ${ }^{10}$.

It is conceivable that a large plum within the slowly convecting mantle might be sufficiently robust to reach this deep layer where it could turn into a plume simply by adding an ' $\mathrm{e}$ ' - where the ' $\mathrm{e}$ ' stands for energy!

1. Morgan, W.J. Nature 230, 42 (1971)

Schilling, J.G. et al. Nature 313, 187 (1985)

Schilling, J.G. Nature 314, 62 (1985).

4. McDougall, I. \& Duncan, R.A. Tectonophysics 63, 275 (1980).

Morgan. W.J. Tectonophysics 94, 123 (1983)

6. Schilling, J.G. \& Noe Nygaard, A. Earth planet. Sci. Lett. 24, 1 (1974).

7. Turcotte, D.L. \& Oxburgh, E.R. Tectonophysics 35, 183 (1976).

8. Duncan, R.A. J. geophys. Res. 89, 9980 (1984).

9. Ringwood, A.F. J. Geol.90, 611 (1982)

10. Zindler. A. et al. Earth planet. Sci Lett. 70. 175 (1984).

Shen-su Sun is in the Division of Petrology and Geochemistry, Bureau of Mineral Resources, Canberra ACT 2601, Australia.

\title{
Endangered species
}

\section{Salvaging single-sex populations}

\section{from Jared M. Diamond}

LAST year I reported in these columns on the narrow escape from extinction of the Chatham Island Black Robin, which had declined to five males and two females (Nature 309, 308; 1984). The rescue of the Dusky Seaside Sparrow (Ammospiza maritima nigrescens) poses a greater challenge, because the three surviving individuals are all males. A programme to salvage its gene pool, directed by Charles Cook and Herbert Kale (Kale, H.W. Bird Conservation 1, 128; 1983 and Florida Naturalist 57(4), 9; 1984), illustrates both the problems encountered in such efforts and the debates over whether the efforts should be undertaken at all.

The Dusky Seaside Sparrow, a local subspecies sometimes considered to be a full species, was formerly abundant in marshes on the east coast of Florida, but in the $1960 \mathrm{~s}$, most of its habitat was destroyed. During the 1970s the US Fish and
Wildlife Service (USFNS) spent five million dollars to save the sparrow by buying its remaining habitat, now the St John's National Wildlife Refuge. This programme failed because of the continuing destruction of the refuge habitat by fires and drainage. The last record of a female bird was in 1976. Finally, in 1979, five of the last six surviving males were brought into captivity for their protection.

At that stage, the only chance to salvage genes of the sparrow was to breed Dusky males first with females of the related Scott's Seaside Sparrow and then with successive generations of resulting hybrid female offspring. Five such crosses would yield birds that were, progressively, 50 , $75,87.5,93.8$ and 96.9 per cent Dusky. Once a large enough flock of 96.9 per cent hybrids had been obtained, some could then be re-established in natural Dusky habitat. To this end, a Dusky male and a
Scott's female were mated experimentally in 1980 , yielding four 50 per cent Dusky hybrids.

For the next two years, while the last Dusky males grew older, USFWS refused not only to fund but even to permit the hybridization programme. When the service finally granted permission in 1983, funds still had to be obtained from private sources: these were given by Wait Disney World, Florida Audubon Society, International Council for Bird Preservation and Wildlife Preservation Trust. In 1983, one 75 per cent Dusky female was produced, followed in 1984 by another 75 per cent chick (not yet sexed) plus a 87.5 per cent chick that, tragically, broke its neck. As the 1985 breeding season approaches, the fate of the Dusky gene pool depends on the three surviving males approaching 10 years of age, which is very old for small temperate-zone songbirds.

This captive breeding programme illustrates vividly two biological difficulties: that small populations are very susceptible to accidents (such as the death of the chick); and that old birds are poor breeding stock. One of the old males has been unsuccessful at wooing females, and another yielded only infertile eggs. In 1984 , the 50 per cent female produced eight clutches and twenty eggs, of which only five hatched and one survived. Thus, a practical message for salvage programmes is to start when there are many youthful survivors, rather than waiting until it is too late, or nearly so.

The broader question raised by the back-crossing programme is whether it is even worth attempting. Some of the objections raised by USFWS were baseless: that hybridization would dilute the Dusky gene pool (but it was doomed other ise); that hybrids might not be fertile (they are); and that hybrids might not resemble the Dusky Seaside Sparrow (they do). However, another objection raises a significant issue: the Service neither wants to spend money on restoring Dusky habitat for eventual releases, nor on saving hybrids. (In the words of one official, "Legally, a 98.4 per cent Dusky isn't a Dusky".) Many biologists similarly object to captive breeding programmes on single species, when money for habitat preservation that could save many species is so scarce. However, the number of species for which captive breeding or backcrossing offers the sole chance of survival is growing rapidly and the current proramme on the California Condor would have been impossible without the experience gained from similar programmes with the Andean Condor and Peregrine Falcon. Thus, although the Dusky Seaside Sparrow is just a small drab bird, the lessons being learned with it now will surely have wider application.

Jared M. Diamond is Professor of Physiology at the University of California Medical School, Los Angeles, California 90024, USA. 